\title{
Foreign Banks and the Business Environment in Transition: A Cointegration Approach
}

\author{
Christopher A. Hartwell \\ Kozminski University \\ Department of International Management \\ Ul. Jagiellonska 57-59 \\ Warsaw, 03-301 \\ Poland \\ e-mail: chartwell@kozminski.edu.pl
}

Received: September 14th 2016

Accepted: March $2^{\text {nd }} 2017$

\begin{abstract}
The contribution of foreign banks to the development of the financial sectors in emerging markets, and especially the transition economies of Central and Eastern Europe, is well-known. The purpose of this article is to focus on an area of foreign bank influence that has thus far only begun to emerge from the extant literature: the effect of foreign banks on the broader business environment in transition. In addition to improving financial intermediation and broader access to credit, has the presence of foreign financial institutions helped to shape a better business environment in the long-run? Or did foreign banks retard local institutional development and thus worsen the overall business environment? Using cointegration techniques across a sample of 21 diverse transition countries from 1983 to 2015, I find that foreign bank entry had a positive impact across business environment indicators, but with some indicators taking longer to influence than others. The policy implications are that business environments can be improved by facilitating foreign bank entry rather than restricting it.
\end{abstract}

Keywords: business environment, foreign bank entry, cointegration, Central and Eastern Europe JEL codes: G15, O16, P33

\section{Introduction}

The contribution of foreign banks to the development of the financial sectors in emerging markets, and especially transition economies, has been well-documented, focusing on the role of foreign banks in mitigating financing constraints on firm entry (Ayyagari et al. 2008) or in contributing to transition processes in a broader sense (Naaborg et. al, 2004). While some articles have highlighted the danger of foreign banks transmitting financial shocks from developed economies (Cetorelli and Goldberg, 2011), for the most part the literature is in agreement that foreign bank entry has been a positive phenomenon in the transition from communism to capitalism.

However, the bulk of work done examining the effects of foreign banks in transition has focused solely on their financial effects, and less on their institutional impact. The purpose of this article is to address this gap in the literature and examine how foreign banks may have contributed to a specific facet of transition beyond purely financial matters. Building on an earlier model (Hartwell and Michael, 2015), this article will examine the effects of foreign bank entry in transition on the development of the business environment in these countries. In addition to improving financial intermediation and building financial access where none existed prior to transition, did foreign financial institutions also help shape a better business environment in transition economies? Put another way, there is ample empirical and theoretical evidence that foreign banks brought in knowhow once they moved into the transition countries of the east, but did they also bring in knowledge of how a business environment should be run? This is a plausible question, given that foreign banks are often the first foreign firms to move into an emerging market, as was the case in transition; being the 
first exposure that formerly-communist policymakers encounter, banks thus have a unique ability to transmit expectations from foreign businesses on how a business environment should operate.

The novelty of this article in the literature regarding both foreign bank entry and transition economics is multi-faceted: in the first instance, there has been little theoretical work done on what are the actual determinants of a country business environment. For instance, why does one country have a longer waiting time at customs than another, or why is one country perceived as more competitive? This article will examine this issue specifically in relation to transition economies, where nearly every country began with a tabula rasa business environment and little institutional memory on how to serve a customer. Our contribution theoretically is to surmise that a business environment is influenced by several factors, including exposure to the outside world, political institutions, macroeconomic conditions, and, the subject of this work, exogenous institutional influence. Can the first 'foreign' institutions entering an economy make a difference on the subsequent path of the business environment?

In addition, there is also little theoretical or empirical work done on how foreign banks can influence the environment around them beyond merely facilitating credit. This article makes a contribution to our understanding of how financial institutions can influence other institutions within an economy. Finally, research into business environment metrics has often ignored the properties of the data, including non-stationarity, a problem plaguing recent attempts in this area (a glaring issue in Kouretas and Tsournas 2016); this article attempts to rectify this gap through the application of cointegration techniques to understand the true long-run relationships between foreign bank entry and the business environment in transition.

The rest of the article as is as follows: the next section examines the admittedly scarce literature surrounding foreign bank entry and a country's business environment, while Section 3 sets up the model and estimation strategy. Section 4 offers the results, and Section 5 concludes with some policy recommendations.

\section{Literature and theory}

A country's business environment is regarded as a sub-set of the broader "investment climate" that prevails within an economy, with the business environment defined as the legislation, regulation, and administration surrounding starting and operating a private-sector business. While the conception of business environment has become standard in economic policymaking, international technical assistance, and even in economics research (Djankov et al. 2002 setting the tone), there is however a dearth of research on the determinants of an effective business environment. Indeed, most work that exists in the extant literature focuses on specific facets of the business environment and their contribution to broader economic metrics rather than offering a theoretical approach into what factors would directly influence a country's investment climate. A notable exception to this trend comes from the OECD (2007), which outlined a basic approach focused more on entrepreneurship than the broader business environment. Their model of demand (market opportunities), supply (presence of skills), and market mechanisms to mediate supply and demand offers a rudimentary way to understand which variables can determine the overall business environments. However, this approach remains in the realm of theoretical, with no follow-up work to test this framework.

Given this lack of work on what exactly determines a country business environment, it is little wonder that there is no examination on the effects of financial institutions on crafting a country's business environment. Recent research from Asturias et. al (2015) has moved us closer to understanding the channels that a foreign bank would utilize to influence the business environment, concentrating on the fact that entry barriers and financial frictions are substitutable. Their work shows that improvements to the financial system have a larger impact on output when entry costs are high, and in many ways, financial sector reform can attain the same effect as removing entry restrictions. 
However, even this work-in-progress does not explore how one path (improved financial intermediation) interacts with the other (reducing barriers to entry).

More specific work from Hartwell and Michael (2015), the direct precursor to this article, comes closest to the issue that we are examining, the effect of foreign banks in improving a country business environment. Examining a large database of developed and developing countries, they develop a thesis that foreign banks can bring in know-how and management techniques that are simply absent from their target market, in addition to contributing financial depth, thus improving the business environment. Their results show, across a broad swath of business environment metrics, that foreign banks do indeed correlate with better business environments, although the biggest gains are in areas that generally require financial intermediation. Put another way, foreign banks can directly impact the facets of the business environment in a developing country in the sectors where banks are present (such as investor protection and cost of trading), with broader business environment metrics less affected (such as contract enforcement). This comports with a thesis advanced in Kouretas and Tsoumas (2016), that foreign banks may improve risk management and funds availability, an effect which would be most pronounced on areas in which banks specialize.

Theoretically, the results that Hartwell and Michael (2015) found for all countries should be even more pronounced in the transition economies in Central and Eastern Europe (CEE) and the former Soviet Union (FSU), where foreign banks filled a large institutional void left after the collapse of communism. Having neither a financial system nor a business environment, foreign banks were amongst the first foreign institutions to enter the newly-transitioning countries, exposing policymakers to "Western" expectations on how business should be conducted. Thus, these institutions would not have only had a major effect on the development of financial sectors throughout the region, they also could have acted as ambassadors of good practice, transmitting know-how and professionalism that translated into better business environments. And as Asturias et. al (2015) surmise, the removal of financial frictions may have also encouraged firm entry, which then would feed into more demand for business environment improvements.

In sum, the entry of foreign banks into transitional economies may not only have provided the effects already noted in the literature, namely access to finance or even better risk-management (or, on the negative side, the possibility of importing foreign risk). In the context of an economy that was undergoing wide-ranging structural changes, the presence of foreign banks may have also led to more efficient business regulations and a transfer of knowledge on the "appropriate" ways in which the private and public sectors should have interacted. While these effects were discerned in Hartwell and Michael (2015), the impact would likely have been much larger in transition economies.

\section{The model}

\subsection{Model and data description}

In order to examine the relationship between business environments and foreign bank presence in transition, a variety of econometric methods will be utilized. The base model relates a series of business environment variables to foreign bank entry:

$$
Y_{i t}{ }^{*}=\alpha X_{i t-1}+\rho \text { ForeignBank }_{t-1}+\varepsilon_{i t}
$$

Where $\mathrm{Y}$ is the specific facet of the business environment in country $i, \mathrm{X}$ is a lagged vector of macroeconomic and institutional controls, and Foreign Bank is the lagged size of foreign bank claims in a given year (taken from the Bank for International Settlements). The lag, at one year, of bank claims and all controls is included to alleviate simultaneity issues and hopefully isolate the effects of foreign bank presence on the myriad of business environment metrics (although the effects may take more than a year to materialize, as will be seen in the regressions below). Given the extremely varying scale of the different variables, all are expressed in log form. 
The Y variables are derived from Hartwell and Michael (2015) and included to encompass a large cross-section of the different facets of a country's business environment. Unlike Kouretas and Tsournos (2016), who use a composite index to proxy for the business environment, I use the separate indicators to better illuminate the specific channels that a bank operates through. These variables include:

- Competitiveness Ranking: From the World Economic Forum's annual rankings, this number captures 12 sub-components and measures competitiveness as the inputs which determine productivity in a country.

- Investor Protection: Obtained from the International Country Risk Guide (ICRG), this index covers three subcomponents (contract viability/expropriation, profit repatriation, and payment delays), each with a maximum score of four points and a minimum score of 0 points, for a total of 12 . Higher numbers correspond to better property rights protection, a key facet of the business environment.

- Days to Start a Business: Taken from the World Bank’s “Ease of Doing Business” rankings, this indicator is simply the number of days it takes to open/register a limited liability corporation in the largest business city of a particular city (in practice, often the capital city).

- Time to Export or Import: Recorded in calendar days, these two measures cover how long the process for either exporting or importing a container takes throughout document preparation, inland transport and handling, customs clearance and inspections, and port and terminal handling.

- Cost to Export or Import: The companion measure to time, the cost of export/import is calculated as the fees levied on a 20 -foot container, in U.S. dollars. This measure includes all fees associated with the four stages of export/import noted in the previous indicator.

Arrayed against these dependent variables, in addition to our metric of interest (foreign bank presence) are a series of macroeconomic and country-characteristic controls. However, in the economics literature, only Hartwell and Michael (2015) having created a plausible set of macroeconomic and policy controls that would account for a country's business environment. Their article examined GDP per capita (following Djankov et al. 2002), population size, openness, inflation, and government growth as possible determinants of specific traits of the business environment, outlining how each particular variable would affect the various facets of the business environment such as time to import or number of days to start a business. Via these controls, they were able to cover many of the other possible determinants of business environment outlined above, with GDP proxying for general economic health of country, growth of government proxying for government size, population size representing inherent transaction costs in a country, and inflation and openness acting as a proxy for government policies more generally.

Following on the lead of this earlier work, this current article includes all of these possible determinants of business environment success or failure, with the exception of swapping out the World Bank's trade as a percentage of GDP measure for the constructed "openness" ratio that was used in the earlier article. Additionally, inflation has been transformed as in Staehr (2005), using a logarithmic formulation of $\log (100+$ inflation rate), in order to account for the episodes of hyperinflation that took place in transition. More importantly, here we extend the analysis by including several additional metrics that could plausibly determine a country's business environment. In the realm of more general controls, we include in this analysis the extent of resource rents in an economy as a percentage of GDP, which can create "Dutch Disease" effects and retard development of nonextractive industries, thus creating a more difficult business environment; this is also the case in many transition economies, where extractive industries have come to both dominate the economy (Russia, Azerbaijan) as well as creating a powerful vested interest against liberalization. Going in the other direction, we also include here gross tertiary enrollment, included to capture human capital effects demand for a better business environment. Finally, in terms of macroeconomic controls, included in 
this revised specification is the net inflow of foreign direct investment, a variable which has been shown to have an impact in encouraging business environment reform (Bevan and Estrin 2004). ${ }^{1}$

As we are focusing on transition countries exclusively, this analysis will also encompass possible determinants of business environment that would be specific to a transitioning economy, including: democratic change, captured here by the Polity IV "polity2" measure which quantifies the extent of political openness and institutional development in a transitioning society. The transition from communism to capitalism was not just an economic one, as political institutions also moved from a one-party state to pluralism, and this change could have affected the business environment developmental path in each country. An expanding voice in the political process could have increased the demand for ease of doing business by entrepreneurs, although, conversely, it also could have allowed populist policies which are harmful to business (e.g. minimum wage laws or protectionism). Finally, although not necessarily specific to transition economies, we have also included the surface area of the country as another indicator of size which may capture scale and transport cost effects in a different manner than population size. The transition process not only entailed changes of institutions, but in many cases changes of borders, with the collapse of the Soviet Union into 15 separate countries, the division of Yugoslavia into six (and eventually seven) new countries, and the peaceful divorce of Czechoslovakia into two separate polities.

The data utilized in this article covers 21 transition economies on an annual basis over the period 1983-2015 (the ICRG investor protection data goes to 1983 while the World Bank Doing Business indicators start only in 2003 and the World Economic Forum data goes back to 2000). ${ }^{2}$ Macroeconomic control data was collected from the IMF and World Bank World Development Indicators, and had full country coverage over the timeframe specified.

\subsection{Data diagnostics and choice of estimator}

Econometric estimation of the model shown in Equation 1 must take into account the exigencies of the data, and with several dependent variables, a "one-size-fits-all” estimator is not possible. This is especially the case in regard to fundamental issues such as the presence of a unit root, which can create spurious or inconsistent regressions unless corrected for. Diagnostic tests on the data were conducted using the Levin Lin Chu (LLC) test for a common unit root and the Im, Pesaran, and Shin (IPS) test, Phillips-Perron (PP) test, and the Augmented Dickey-Fuller (ADF) test to test for an individual unit root. Results shown in Table 1 below confirm that all our dependent variables are nonstationary at their levels and are integrated at the order I(1). In regard to independent variables, the key explanator of foreign bank claims is also non-stationary, with other macroeconomic controls also appearing to exhibit a unit root. In particular, GDP per capita, tertiary enrollment, and a country's surface area all are also integrated on the order of $\mathrm{I}(1) .^{3}$ All other variables are stationary and integrated at $\mathrm{I}(0)$.

Given these results, in order to provide consistent estimation, we are faced with either differencing the data or utilizing any number of cointegration methods. As differencing would likely wipe away much of the information that we are after, the choice of this article is to apply cointegration techniques to understand the long-run relationships between our variables and the business environment. As we need to establish cointegration amongst our non-stationary variables in order to use these techniques, however, I apply a full complement of cointegration tests, including the Pedroni

\footnotetext{
${ }^{1}$ Thanks to an anonymous referee for suggesting its inclusion.

${ }^{2}$ The countries included in the dataset are Albania, Armenia, Azerbaijan, Bulgaria, Croatia, the Czech Republic, Estonia, Georgia, Hungary, Kazakhstan, Latvia, Lithuania, Macedonia (FYROM), Moldova, Poland, Romania, Russia, Slovakia, Slovenia, Tajikistan, and Ukraine.

${ }^{3}$ For GDP per capita, a "tie-breaker" was required, as two of four tests showed stationarity. To break the tie, the Breitung unit root test was performed, showing a Breitung $p$-value of 1.00 and confirming the nonstationarity of GDP per capita. All variables containing a unit root were further tested and shown to be difference-stationary; results are omitted for sake of space but available from the author.
} 
residual test, the Kao (1999) panel test, and the Fisher-Johansen test, to determine cointegration amongst the non-stationary variables. The full set of tests are shown in Appendix A for each dependent variable, but uniformly the Pedroni and Kao tests establish that cointegration exists among the non-stationary variables while the Fisher-Johansen test also strongly supports cointegration relationships among all of the included variables and for each dependent variable.

These results allow us to use an ordinary least squares model corrected for the cointegrating vectors which, in this instance, will be the panel dynamic ordinary least square (PDOLS) model of Mark and Sul (2003). Our usage of PDOLS follows the approach of Brambila-Macias and Massa (2010), Kakkar and Yan (2011), and Canale et.al (2014), as PDOLS has several traits to recommend it for the particular data amassed here. In the first instance, according to Mark and Sul (2003:655), PDOLS should "allow for individual heterogeneity through disparate short-run dynamics, individualspecific fixed effects and individual-specific time trends." Such an emphasis on fixed-effects is important for our data, as a Redundant Fixed-Effects Test in Eviews returned a $p$-value of 0.000 (chisquare statistic of 341.59), confirming the significance of country fixed-effects in the specification. Additional tests on the joint significance of period and country fixed-effects returned a similar result, with a chi-square of 355.98 and a $p$-value of 0.000 , showing that a within-estimator such as PDOLS is appropriate for our purposes.

Furthermore, an added advantage of the PDOLS process as utilized here is that pre-whitening in the manner of Andrews and Monahan (1992), utilizing a Bartlett kernel and Newey-West automatic bandwidth for the long-run variance, results in standard errors which are robust to both heteroskedasticity and autocorrelation. Finally, PDOLS as shown in Mark and Sul (2003) allows for some degree of cross-sectional dependence (Gnimassoun and Coulibaly 2014), but additional Pesaran (2004) tests across each model gave little evidence of cross-sectional dependence in the data. ${ }^{4}$

\section{Results}

The results of this empirical analysis are shown in Table 2 below. Across all specifications and, surprisingly, all metrics, the results are uniform: foreign bank presence aids in the improvement of all facets of business reform in transition, confirming the results of Hartwell and Michael (2015) on a larger sample of developed and developing countries. However, these effects take some time to work their way into the system, as the beneficial effects of foreign bank entry are often not seen until three years later or even five years later in a transition economy. In fact, it is only for the time to start a business, time to import, and cost of exporting goods that foreign bank presence has an immediate and significant effect, while for other metrics the effect is insignificant at its first lag. The inclusion of longer lags of foreign bank presence corrects this anomaly uniformly, once again pointing to the fact that bank entry can encourage a better business environment but that it may require several years to work its way into a country's institutional structure.

When correcting for this delay, against each dependent variable, the longer-term effects of foreign bank entry have a strong positive economic and statistical effect, with the strongest results in regard to a country's competitiveness rank and the time it takes to start a business. For example, if a country were to double its stock of foreign bank claims at time $t-3$, this would correspond to an increase in its competitiveness ranking of approximately 4.73 places closer to the top. Similar results hold for each metric, with investor protection and time to export showing improvement at a longer lag (at least five-years) of foreign bank entry (prior to that, foreign bank entry has a beneficial impact but is insignificant). These results hold up in the presence of the full set of macroeconomic and countryspecific controls, which behave for the most part as expected: more trade leads to better trade administration through familiarity and much higher competitiveness while poor macroeconomics (such as inflation) creates difficulties in a business environments, on average.

\footnotetext{
${ }^{4}$ The Pesaran test was chosen for its small sample properties, which characterizes most of the models described below. Results available from the author.
} 
As a robustness test for these results, it is interesting to note the impact of other possible determinants that are specific to transition countries. In the first instance, accession to the EU was a goal for many of the countries in this sample, possibly shaping the course of a particular business environment as the country converged on EU standards. Conversely, some countries in our database were unlikely to ever achieve EU accession (Tajikistan or Azerbaijan), and thus it is plausible that their business environments pursued a more independent path. To account for this reality, a dummy variable was included that takes the value of 1 in the year a country entered the EU (and every year thereafter) and 0 if otherwise. Various leads and lags will be experimented with to account for preparation effects.

The results of this test are shown in Table 3, and the addition of an EU dummy does not alter the basic time structure or magnitude of foreign bank influence; indeed, in many areas, it strengthens the relationship, as in the advance of foreign bank influence in cost to import from three years out to just one and the much higher reductions in costs of exporting. Moreover, the EU dummy itself is fairly insignificant in most specifications, although it appears that being an EU country means having lower investor protections on average and more red tape in starting a business, a plausible assumption given that countries preparing for EU accession had to adopt a large number of EU regulations and directives, ones which were likely much more onerous than a country that had no such aspirations. Perhaps reassuringly, the EU has succeeded in lowering trade costs for its members who also were transition economies, at least in terms of time and cost of exporting.

As a final robustness test, perhaps it was not the economic conditions, EU accession, or presence of foreign banks that contributed to the improvement of the business environment in transition, but the transition process itself; that is, perhaps it was the package of reforms that these countries were undergoing as part of transition that were the prime movers of improving the investment climate. To test this possibility, we re-run the dynamic OLS regressions with an additional regressor, the EBRD's indicator for "governance and enterprise restructuring," as a proxy for a country's overall enterprise sector reforms. This index, as with all EBRD indicators, is coded from 1 to 4.33, with a 1 showing no change from communist times and a 4.33 showing convergence with Western European standards of corporate governance. The results of including this indicator are shown in (streamlined) Table 4, and, while restructuring is incredibly important for business environment metrics, it does not vitiate the results of foreign bank entry. The only metric which is affected by the inclusion of the governance index is a slight reduction in effect and significance of foreign banks on the time needed to start a business, but the difference still remains significant at the $5 \%$ level. In all other cases, the relationship between foreign bank entry and an improved business environment holds.

\section{Conclusions}

The results shown above confirm earlier work done in Hartwell and Michael (2015) on the effect of foreign bank entry on a country's business environment, but extend the analysis for additional years and are much stronger than this earlier work. Focusing exclusively on transition economies, we find that foreign bank entry, especially if seen from a longer-run trend (3 years or more), contributes positively to various facets of a country's business environment, including its competitiveness and the time it takes to trade. These results were robust to inclusion of various macroeconomic and countryspecific traits that could be plausibly hypothesized as having an effect on the business environment.

The research that may follow from this article is also promising and varied but would likely continue to focus on understanding how policies, institutions, and macroeconomic conditions feed through to the overall business environment. Indeed, as noted throughout this article, the dearth of work explaining why a particular country has a longer time to start a business than another is an interesting omission from the political economy literature. With a longer time-series of various business environment metrics, and through the use of appropriate estimation techniques (including 
accounting for possible endogeneity), such issues could be easily tackled, but only with a supporting theoretical framework. These results will then help to guide better policy in emerging markets and in developed economies. As shown in this preliminary analysis, there is already an obvious recommendation to encourage foreign financial institutions to enter a country, given their beneficial role in the business environment.

\section{Acknowledgements}

The author wishes to thank Mikhail Volkov for his research assistance, Bryane Michael and Sushanta Mallick for their comments, and the organizers of the 15th International Conference on Finance and Banking held in Prague for their support.

\section{References}

Andrews, D. W. K., \& Monahan, J. C. (1992). An Improved Heteroskedasticity and Autocorrelation Consistent Covariance Matrix Estimator. Econometrica, 60(4), 953-966.

Asturias, J., Hur, S., Kehoe, T. J., Ruhl, K. J. (2015). The Interaction of Entry Barriers and Financial Frictions in Growth. Federal Reserve Bank of Minneapolis Research Department Staff Report. Minneapolis: Federal Reserve Bank.

Ayyagari, M., Demirgüç-Kunt, A., \& Maksimovic, V. (2008). How important are financing constraints? The role of finance in the business environment. The World Bank Economic review, 22(3), 483-516.

Bevan, A.A., \& Estrin, S. (2004). The determinants of foreign direct investment into European transition economies. Journal of Comparative Economics, 32(4), 775-787.

Brambila

Africa: the effects of slowing private capital inflows on growth. African Development Review, 22(3), 366-377.

Canale, R. R., Liotti, G., \& Napolitano, O. (2014). Structural public balance adjustment effects on growth in 25 OECD countries and the Eurozone. Comparative Economic Studies, 56(4), 635-656.

Cetorelli, N., \& Goldberg, L. S. (2011). Global banks and international shock transmission: Evidence from the crisis. IMF Economic Review, 59(1), 41-76.

Djankov, S., La Porta, R., Lopez-de-Silanes, F., \& Shleifer, A. (2002). The regulation of entry. Quarterly Journal of Economics, 117(1), 1-37.

Gnimassoun, B., \& Coulibaly, I. (2014). Current account sustainability in Sub-Saharan Africa: Does the exchange rate regime matter? Economic Modelling, 40, 208-226.

Hadri, K. (2000). Testing for stationarity in heterogeneous panel data. The Econometrics Journal, 3(2), 148-161.

Hartwell, C. A., \& Michael, B. (2015). A helping hand: examining the effect of foreign banks on the business environment. International Journal of Emerging Markets, 10(4), 875-895. 
Kakkar, V., \& Yan, I. K. (2011). Sectoral Capital-Labor Ratios and Total Factor Productivity: Evidence from Asia. Review of International Economics, 19(4), 674-684.

Kao, C. (1999). Spurious regression and residual-based tests for cointegration in panel data. Journal of Econometrics, 90(1), 1-44.

Kouretas, G. P., \& Tsoumas, C. (2016). Foreign bank presence and business regulations. Journal of Financial Stability, 24, 104-116.

Mark, N. C., \& Sul, D. (2003). Cointegration vector estimation by panel DOLS and long - run money demand. Oxford Bulletin of Economics and Statistics, 65(5), 655-680.

Naaborg, I., Scholtens, B., De Haan, J., Bol, H., \& De Haas, R. (2004). How important are foreign banks in the financial development of European transition countries? Journal of Emerging Market Finance, 3(2), 99-123.

OECD (2007). Micro-Policies for Growth and Productivity. Paris: Organization for Economic Cooperation and Development.

Pesaran, M.H. (2004). General Diagnostic Tests for Cross Section Dependence in Panels (Discussion Article No. 1240). IZA Institute for Labor Economics: Bonn.

Staehr, K. (2005). Reforms and Economic Growth in Transition Economies: Complementarity, Sequencing and Speed. The European Journal of Comparative Economics, 2(2), 177-202. 
Table 1: Results of Unit Root Tests

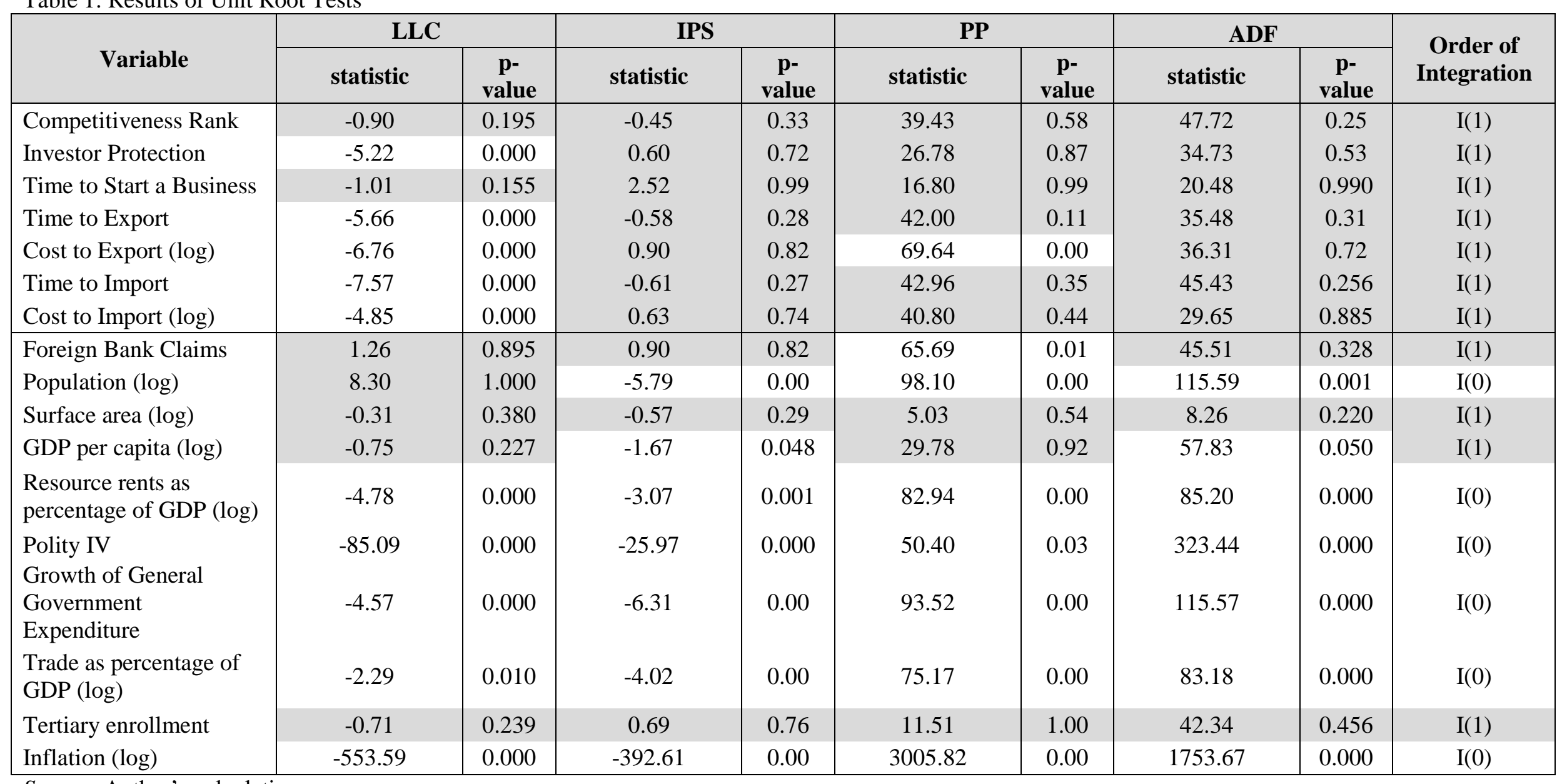

Source: Author's calculations 
Table 2: Effects of Foreign Bank Presence on the Business Environment, PDOLS Specification

\begin{tabular}{|c|c|c|c|c|c|c|c|c|c|c|c|}
\hline & \multicolumn{2}{|c|}{ Competitiveness Rank } & \multicolumn{2}{|c|}{ Investor Protection } & \multirow{2}{*}{\begin{tabular}{|c}
$\begin{array}{c}\text { Time to } \\
\text { Start a } \\
\text { Business }\end{array}$ \\
5
\end{tabular}} & \multirow{2}{*}{$\begin{array}{c}\text { Time to } \\
\text { Import }\end{array}$} & \multicolumn{2}{|c|}{ Cost to Import (log) } & \multicolumn{2}{|c|}{ Time to Export } & \multirow{2}{*}{$\begin{array}{c}\begin{array}{c}\text { Cost to } \\
\text { Export (log) }\end{array} \\
11\end{array}$} \\
\hline & 1 & 2 & 3 & 4 & & & 7 & 8 & 9 & 10 & \\
\hline Foreign Bank Claims (-1) & 4.23 & & -0.04 & & -4.89 & -0.06 & 0.002 & & -0.01 & & -0.01 \\
\hline & 1.50 & & 0.18 & & $3.62 * * *$ & $3.01^{* * *}$ & 0.23 & & 0.45 & & $10.54^{* * *}$ \\
\hline Foreign Bank Claims (-3) & & $\begin{array}{c}-4.73 \\
2.21 * *\end{array}$ & & & & & & $\begin{array}{c}-0.04 \\
3.81 * * *\end{array}$ & & & \\
\hline Foreign Bank Claims (-5) & & & & $\begin{array}{c}0.78 \\
5.74^{* * *}\end{array}$ & & & & & & $\begin{array}{c}-0.08 \\
13.52^{* * *}\end{array}$ & \\
\hline \multirow[t]{2}{*}{ GDP per capita } & -13.52 & -4.69 & -1.70 & -1.19 & -21.12 & -0.09 & 0.07 & 0.04 & 0.06 & 0.04 & 0.10 \\
\hline & $1.92 *$ & 0.93 & $4.28 * * *$ & $3.38 * * *$ & $6.10^{* * *}$ & $2.31 * *$ & $4.11 * *$ & $1.99 * *$ & $2.36^{* *}$ & $3.02 * * *$ & $5.98 * * *$ \\
\hline \multirow[t]{2}{*}{ Population } & -62.29 & -19.57 & -68.58 & -68.51 & -297.88 & 36.32 & -0.32 & -2.76 & 1.17 & -2.30 & -1.69 \\
\hline & 0.38 & 0.12 & $5.48 * * *$ & $5.55^{* * *}$ & $2.23^{* *}$ & $23.20 * * *$ & $7.82^{* * *}$ & $6.07^{* * *}$ & 1.07 & $3.09 * * *$ & $3.28^{* * *}$ \\
\hline \multirow[t]{2}{*}{ Surface Area } & 10144.64 & 11311.73 & 163.48 & 127.03 & 9102.82 & -198.12 & -17.64 & -39.72 & 78.55 & 105.01 & -0.91 \\
\hline & $1.85^{*}$ & $2.06 * *$ & $1.78^{*}$ & 1.41 & $5.97 * * *$ & $9.38 * * *$ & 0.74 & $1.72 *$ & $6.65 * * *$ & $18.44^{* * *}$ & 0.04 \\
\hline \multirow[t]{2}{*}{ Trade to GDP } & -42.88 & -46.98 & -0.34 & -0.54 & 17.58 & -0.31 & -0.22 & -0.35 & -0.04 & -0.13 & -0.20 \\
\hline & $4.43^{* * *}$ & $4.71 * * *$ & 0.44 & 0.71 & $2.64^{* *}$ & $4.25 * * *$ & $9.66 * * *$ & $11.96^{* * *}$ & 0.77 & $4.50 * * *$ & $7.88^{* * *}$ \\
\hline \multirow[t]{2}{*}{ Government Growth } & 0.21 & 0.08 & 0.08 & 0.06 & -0.21 & -0.02 & 0.001 & 0.002 & -0.005 & -0.008 & 0.002 \\
\hline & 1.02 & 0.38 & $5.36^{* * *}$ & $3.93 * * *$ & 1.59 & $7.93^{* * *}$ & $2.40 * *$ & $3.11^{* * *}$ & $3.31 * * *$ & $8.25^{* * *}$ & $3.25 * * *$ \\
\hline \multirow[t]{2}{*}{ Resource Rents to GDP } & -3.42 & -4.08 & 0.41 & 0.15 & 0.51 & 0.11 & 0.05 & 0.05 & 0.02 & 0.02 & 0.05 \\
\hline & 1.11 & 1.33 & $2.47^{* *}$ & 0.88 & 0.24 & $4.86^{* *}$ & $7.26 * * *$ & $6.46 * * *$ & 1.51 & $3.53 * * *$ & $6.94 * * *$ \\
\hline \multirow[t]{2}{*}{ Inflation } & -844.84 & -368.35 & 20.03 & 20.18 & 7287.18 & 23.34 & 15.70 & 42.94 & 8.27 & 37.17 & 31.05 \\
\hline & 0.59 & 0.25 & 1.29 & 1.04 & $6.98 * *$ & $1.85^{*}$ & $2.36^{* *}$ & $5.64 * * *$ & 0.92 & $7.15^{* * *}$ & $5.58 * * *$ \\
\hline \multirow[t]{2}{*}{ FDI Net Inflows } & 0.36 & 0.35 & 0.01 & 0.001 & 0.22 & 0.001 & -0.001 & -0.0004 & -0.0001 & 0.0003 & -0.0004 \\
\hline & $13.06 * * *$ & $12.89 * * *$ & 1.14 & 1.24 & $2.45 * *$ & 1.46 & $6.38 * * *$ & $3.84 * * *$ & 0.66 & $2.09 * *$ & $4.13 * * *$ \\
\hline \multirow[t]{2}{*}{ Tertiary Enrollment } & -0.26 & -0.25 & 0.001 & -0.001 & -0.02 & 0.007 & 0.001 & 0.002 & 0.001 & -0.001 & 0.0001 \\
\hline & $4.09 * * *$ & $3.81 * * *$ & 0.09 & 0.05 & 0.37 & $5.94 * * *$ & $2.45^{* *}$ & $4.03 * * *$ & 1.53 & $3.34 * * *$ & $2.13^{* *}$ \\
\hline \multirow[t]{2}{*}{ Polity } & 0.67 & 0.68 & 0.005 & 0.005 & -1.05 & -0.02 & 0.004 & 0.004 & 0.001 & -0.01 & 0.009 \\
\hline & 0.65 & 0.69 & $3.85^{* * *}$ & $3.63 * * *$ & 1.69 & $3.47^{* * *}$ & 1.27 & 1.09 & 0.27 & $5.17^{* * *}$ & $3.35^{* * *}$ \\
\hline $\mathrm{n}$ & 241 & 241 & 261 & 250 & 216 & 180 & 180 & 180 & 180 & 180 & 180 \\
\hline Adjusted R-squared & 0.91 & 0.91 & 0.92 & 0.92 & 0.80 & 0.95 & 0.97 & 0.97 & 0.95 & 0.95 & 0.97 \\
\hline cointegrating trend & linear & linear & $\begin{array}{l}\text { linear and } \\
\text { quadratic }\end{array}$ & $\begin{array}{l}\text { linear and } \\
\text { quadratic }\end{array}$ & linear & linear & $\begin{array}{l}\text { linear and } \\
\text { quadratic }\end{array}$ & $\begin{array}{l}\text { linear and } \\
\text { quadratic }\end{array}$ & linear & linear & $\begin{array}{l}\text { linear and } \\
\text { quadratic }\end{array}$ \\
\hline long-run variance & 0.0004 & 0.0004 & 0.30 & 0.29 & 0.31 & 0.004 & 0.0001 & 0.0001 & 0.001 & 0.001 & 0.004 \\
\hline
\end{tabular}

Note: absolute values of t-stats are under the coefficients, with * signifying significance at the $10 \%$ level, ** at the $5 \%$ level, and *** at the $1 \%$ level. 
Table 3 - Robustness Tests including EU Accession

\begin{tabular}{|c|c|c|c|c|c|c|c|c|c|c|}
\hline & \multicolumn{2}{|c|}{$\begin{array}{l}\text { Competitiveness } \\
\text { Rank }\end{array}$} & \multicolumn{2}{|c|}{ Investor Protection } & \multirow{2}{*}{$\begin{array}{c}\begin{array}{c}\text { Time to } \\
\text { Start a } \\
\text { Business }\end{array} \\
5\end{array}$} & \multirow{2}{*}{$\begin{array}{c}\text { Time to } \\
\text { Import }\end{array}$} & \multirow{2}{*}{$\begin{array}{c}\begin{array}{c}\text { Cost to } \\
\text { Import } \\
\text { (log) }\end{array} \\
7\end{array}$} & \multicolumn{2}{|c|}{ Time to Export } & \multirow{2}{*}{$\begin{array}{c}\begin{array}{c}\text { Cost to } \\
\text { Export } \\
\text { (log) }\end{array} \\
10\end{array}$} \\
\hline & 1 & 2 & 3 & 4 & & & & 8 & 9 & \\
\hline & $\begin{array}{l}4.29 \\
1.51\end{array}$ & & $\begin{array}{l}-0.13 \\
0.57\end{array}$ & & $\begin{array}{c}-5.43 \\
7.11^{* * *}\end{array}$ & $\begin{array}{l}-0.06 \\
2.47^{* *}\end{array}$ & $\begin{array}{c}-0.03 \\
2.99 * * *\end{array}$ & $\begin{array}{l}-0.02 \\
1.47\end{array}$ & & $\begin{array}{c}-0.08 \\
7.85^{* * *}\end{array}$ \\
\hline Foreign Bank Claims (-3) & & $\begin{array}{c}-4.54 \\
2.10^{* *}\end{array}$ & & & & & & & & \\
\hline Foreign Bank Claims $(-5)$ & & & & $\begin{array}{c}0.63 \\
4.68^{* * *}\end{array}$ & & & & & $\begin{array}{c}-0.05 \\
6.17^{* * *}\end{array}$ & \\
\hline EU dummy & 1.1 & 0.90 & -0.29 & -0.31 & 3.60 & -0.02 & -0.005 & -0.03 & -0.03 & -0.009 \\
\hline & 0.78 & 0.63 & $2.20^{* *}$ & $2.43^{* *}$ & $4.43^{* * *}$ & 0.32 & 0.35 & $2.40^{* *}$ & $2.56^{* * *}$ & $2.78^{* * *}$ \\
\hline $\mathrm{n}$ & 240 & 240 & 261 & 250 & 216 & 180 & 180 & 180 & 180 & 180 \\
\hline Adjusted R-squared & 0.91 & 0.91 & 0.90 & 0.90 & 0.84 & 0.95 & 0.95 & 0.95 & 0.95 & 0.96 \\
\hline cointegrating trend & linear & linear & $\begin{array}{c}\text { linear } \\
\text { and } \\
\text { quadratic }\end{array}$ & $\begin{array}{c}\text { linear } \\
\text { and } \\
\text { quadratic }\end{array}$ & $\begin{array}{c}\text { linear } \\
\text { and } \\
\text { quadratic }\end{array}$ & linear & linear & linear & linear & linear \\
\hline long-run variance & 48.39 & 48.24 & 0.30 & 0.27 & 13.24 & 0.004 & 0.0007 & 0.001 & 0.001 & 0.005 \\
\hline
\end{tabular}

Note: absolute values of $t$-stats are under the coefficients, with * signifying significance at the $10 \%$ level, ** at the $5 \%$ level, and *** at the $1 \%$ level. Macroeconomic controls are retained in the regressions but not shown in interests of space. 
Table 4 - Robustness Tests including Enterprise Restructuring

\begin{tabular}{|c|c|c|c|c|c|c|c|c|c|}
\hline & \multicolumn{2}{|c|}{$\begin{array}{c}\text { Competitiveness } \\
\text { Rank }\end{array}$} & \multicolumn{2}{|c|}{ Investor Protection } & \multirow{2}{*}{$\begin{array}{c}\begin{array}{c}\text { Time to } \\
\text { Start a } \\
\text { Business }\end{array} \\
5\end{array}$} & \multirow{2}{*}{$\begin{array}{c}\text { Time to } \\
\text { Import }\end{array}$} & \multirow{2}{*}{$\begin{array}{c}\text { Cost to } \\
\text { Import } \\
\text { (log) }\end{array}$} & \multirow{2}{*}{$\begin{array}{c}\text { Time to } \\
\text { Export }\end{array}$} & \multirow{2}{*}{$\begin{array}{c}\text { Cost to } \\
\text { Export } \\
\text { (log) }\end{array}$} \\
\hline & 1 & 2 & 3 & 4 & & & & & \\
\hline Foreign Bank Claims (-1) & $\begin{array}{l}2.16 \\
1.02\end{array}$ & & $\begin{array}{l}-0.47 \\
1.11\end{array}$ & & $\begin{array}{c}-3.01 \\
2.51 * *\end{array}$ & $\begin{array}{c}-0.07 \\
2.55^{* * *}\end{array}$ & $\begin{array}{c}-0.05 \\
4.64 * * *\end{array}$ & $\begin{array}{c}-0.10 \\
4.77 * * *\end{array}$ & $\begin{array}{c}-0.07 \\
3.75^{* * *}\end{array}$ \\
\hline Foreign Bank Claims (-3) & & $\begin{array}{c}-5.43 \\
2.40 * *\end{array}$ & & & & & & & \\
\hline Foreign Bank Claims (-5) & & & & $\begin{array}{c}0.63 \\
4.64^{* * *}\end{array}$ & & & & & \\
\hline \multirow[t]{2}{*}{ EBRD governance and enterprise index } & 2.20 & 2.12 & 1.61 & -0.06 & -13.30 & -0.005 & -0.05 & -0.01 & -0.05 \\
\hline & 1.11 & 0.73 & $3.72 * * *$ & 0.26 & $9.48 * * *$ & 0.15 & $4.01 * * *$ & 0.31 & $2.95 * * *$ \\
\hline \multirow[t]{2}{*}{ EU dummy } & 4.21 & 0.61 & -0.36 & -0.31 & 5.83 & -0.006 & -0.003 & -0.10 & -0.01 \\
\hline & $4.41 * * *$ & 0.43 & 1.27 & $2.41 * *$ & $8.41 * * *$ & 0.13 & 0.15 & $2.93 * * *$ & $2.08 * *$ \\
\hline $\mathrm{n}$ & 240 & 240 & 261 & 250 & 216 & 180 & 180 & 180 & 180 \\
\hline Adjusted R-squared & 0.93 & 0.91 & 0.89 & 0.90 & 0.89 & 0.95 & 0.96 & 0.90 & 0.96 \\
\hline cointegrating trend & $\begin{array}{c}\text { linear } \\
\text { and } \\
\text { quadratic }\end{array}$ & linear & $\begin{array}{c}\text { linear } \\
\text { and } \\
\text { quadratic }\end{array}$ & $\begin{array}{c}\text { linear } \\
\text { and } \\
\text { quadratic }\end{array}$ & $\begin{array}{c}\text { linear } \\
\text { and } \\
\text { quadratic }\end{array}$ & linear & linear & linear & linear \\
\hline long-run variance & 14.25 & 48.58 & 0.29 & 0.27 & 11.08 & 0.003 & 0.0007 & 0.02 & 0.0005 \\
\hline
\end{tabular}

Note: absolute values of $t$-stats are under the coefficients, with * signifying significance at the $10 \%$ level, ** at the 5\% level, and *** at the $1 \%$ level. Macroeconomic controls are retained in the regressions but not shown in interests of space. 


\section{APPENDIX A - Full Cointegration Test Results}

Dependent Variable: Competitiveness Rank

Independent Variables: Foreign Bank Claims, GDP Per Capita, Tertiary School Enrollment

\begin{tabular}{|l|c|c|c|c|}
\hline \multicolumn{5}{|c|}{ Pedroni Residual Cointegration Test } \\
\hline \multicolumn{4}{|c|}{ Common AR coefficients (within-dimension) } & \multicolumn{2}{c|}{ Weighted } \\
\hline & Statistic & $\boldsymbol{p}$-value & Statistic & $\boldsymbol{p}$-value \\
\hline $\begin{array}{l}\text { Panel PP- } \\
\text { Statistic }\end{array}$ & -1.430 & 0.076 & -2.220 & 0.013 \\
\hline $\begin{array}{l}\text { Panel ADF- } \\
\text { Statistic }\end{array}$ & -3.464 & 0.000 & -4.281 & 0.000 \\
\hline
\end{tabular}

\begin{tabular}{|l|c|c|}
\hline \multicolumn{3}{|c|}{ Individual AR coefficients (between-dimension) } \\
\hline & Statistic & p-value \\
\hline $\begin{array}{l}\text { Group PP- } \\
\text { Statistic }\end{array}$ & -4.180 & 0.000 \\
\hline $\begin{array}{l}\text { Group ADF- } \\
\text { Statistic }\end{array}$ & -4.987 & 0.000 \\
\hline
\end{tabular}

\begin{tabular}{|l|r|r|}
\cline { 2 - 3 } \multicolumn{1}{c|}{} & \multicolumn{2}{c|}{ Kao Residual Test } \\
\cline { 2 - 3 } \multicolumn{1}{c|}{} & t-Statistic & Probability \\
\hline ADF & -4.7518 & 0.000 \\
\hline
\end{tabular}

\begin{tabular}{|c|c|c|c|c|}
\hline \multicolumn{5}{|c|}{ Johansen Fisher Panel Cointegration Test } \\
\hline $\begin{array}{l}\text { Hypothesized } \\
\text { number of } \\
\text { CEs }\end{array}$ & $\begin{array}{c}\text { Fisher } \\
\text { Statistic } \\
\text { (trace) }\end{array}$ & Probability & $\begin{array}{c}\text { Fisher } \\
\text { Statistic } \\
\text { (max } \\
\text { eigen } \\
\text { test) }\end{array}$ & Probability \\
\hline None & 269.50 & 0.000 & 233.00 & 0.000 \\
\hline At most 1 & 225.30 & 0.000 & 154.90 & 0.000 \\
\hline At most 2 & 122.70 & 0.000 & 93.13 & 0.000 \\
\hline At most 3 & 77.76 & 0.000 & 77.76 & 0.000 \\
\hline
\end{tabular}


Dependent Variable: Investor Protection

Independent Variables: Foreign Bank Claims, GDP Per Capita, Tertiary School Enrollment

\begin{tabular}{|c|c|c|c|c|}
\hline \multicolumn{5}{|c|}{ Pedroni Residual Cointegration Test } \\
\hline \multicolumn{5}{|c|}{ Common AR coefficients (within-dimension) } \\
\hline & & & & \\
\hline & Statistic & $p$-value & Statistic & $p$-value \\
\hline $\begin{array}{l}\text { Panel PP- } \\
\text { Statistic }\end{array}$ & -2.376 & 0.009 & -2.324 & 0.01 \\
\hline $\begin{array}{l}\text { Panel ADF- } \\
\text { Statistic }\end{array}$ & -2.833 & 0.002 & -1.827 & 0.03 \\
\hline
\end{tabular}

\begin{tabular}{|l|c|c|}
\hline \multicolumn{3}{|c|}{ Individual AR coefficients (between-dimension) } \\
\hline & Statistic & $\boldsymbol{p}$-value \\
\hline $\begin{array}{l}\text { Group PP- } \\
\text { Statistic }\end{array}$ & -4.286 & 0.0000 \\
\hline $\begin{array}{l}\text { Group ADF- } \\
\text { Statistic }\end{array}$ & -3.669 & 0.0001 \\
\hline
\end{tabular}

\begin{tabular}{|l|c|c|}
\cline { 2 - 3 } \multicolumn{1}{c|}{} & \multicolumn{2}{c|}{ Kao Residual Test } \\
\cline { 2 - 3 } \multicolumn{1}{c|}{} & t-Statistic & Probability \\
\hline ADF & -6.52 & 0.0000 \\
\hline
\end{tabular}

\begin{tabular}{|c|c|l|c|l|}
\hline \multicolumn{5}{|c|}{ Johansen Fisher Panel Cointegration Test } \\
\hline $\begin{array}{l}\text { Hypothesized } \\
\text { number of } \\
\text { CEs }\end{array}$ & $\begin{array}{c}\text { Fisher } \\
\text { Statistic } \\
\text { (trace) }\end{array}$ & Probability & $\begin{array}{c}\text { Fisher } \\
\text { Statistic } \\
\text { (max } \\
\text { eigen } \\
\text { test) }\end{array}$ & Probability \\
\hline None & 214.30 & 0.0000 & 160.60 & 0.0000 \\
\hline At most 1 & 215.20 & 0.0000 & 195.90 & 0.0000 \\
\hline At most 2 & 160.00 & 0.0000 & 142.60 & 0.0000 \\
\hline At most 3 & 89.08 & 0.0000 & 89.08 & 0.0000 \\
\hline
\end{tabular}


Dependent Variable: Time to Start a Business

Independent Variables: Foreign Bank Claims, GDP Per Capita, Tertiary School Enrollment

\begin{tabular}{|c|c|c|c|c|}
\hline \multicolumn{5}{|c|}{ Pedroni Residual Cointegration Test } \\
\hline \multicolumn{5}{|c|}{ Common AR coefficients (within-dimension) } \\
\hline & & & Wei & \\
\hline & Statistic & $p$-value & Statistic & $p$-value \\
\hline Panel PP-Statistic & -4.999 & 0.000 & -11.663 & 0.00 \\
\hline Panel ADF-Statistic & -3.590 & 0.000 & -5.820 & 0.00 \\
\hline
\end{tabular}

\begin{tabular}{|l|c|c|}
\hline \multicolumn{3}{|l|}{ Individual AR coefficients (between-dimension) } \\
\hline & Statistic & $\boldsymbol{p}$-value \\
\hline Group PP-Statistic & -16.137 & 0.000 \\
\hline Group ADF-Statistic & -5.790 & 0.000 \\
\hline
\end{tabular}

\begin{tabular}{|l|c|c|}
\cline { 2 - 3 } \multicolumn{1}{c|}{} & \multicolumn{2}{c|}{ Kao Residual Test } \\
\cline { 2 - 3 } \multicolumn{1}{c|}{} & t-Statistic & Probability \\
\hline ADF & -4.878 & 0.000 \\
\hline
\end{tabular}

\begin{tabular}{|c|c|c|c|c|}
\hline \multicolumn{5}{|c|}{ Johansen Fisher Panel Cointegration Test } \\
\hline Hypothesized number of CEs & $\begin{array}{c}\text { Fisher } \\
\text { Statistic } \\
\text { (trace) }\end{array}$ & Probability & $\begin{array}{c}\text { Fisher } \\
\text { Statistic } \\
\text { (max } \\
\text { eigen } \\
\text { test) }\end{array}$ & Probability \\
\hline None & 168.60 & 0.000 & 114.70 & 0.000 \\
\hline At most 1 & 78.09 & 0.000 & 44.14 & 0.007 \\
\hline At most 2 & 55.84 & 0.000 & 45.11 & 0.006 \\
\hline At most 3 & 46.72 & 0.004 & 46.72 & 0.004 \\
\hline
\end{tabular}


Dependent Variable: Time to Start a Business

Independent Variables: Foreign Bank Claims, GDP Per Capita

\begin{tabular}{|c|c|c|c|c|}
\hline \multicolumn{5}{|c|}{ Pedroni Residual Cointegration Test } \\
\hline \multicolumn{5}{|c|}{ Common AR coefficients (within-dimension) } \\
\hline & & & Wei & \\
\hline & Statistic & $p$-value & Statistic & $p$-value \\
\hline Panel PP-Statistic & -4.547 & 0.000 & -6.247 & 0.00 \\
\hline Panel ADF-Statistic & -3.285 & 0.001 & -3.994 & 0.00 \\
\hline
\end{tabular}

\begin{tabular}{|l|c|c|}
\hline \multicolumn{3}{|l|}{ Individual AR coefficients (between-dimension) } \\
\hline & Statistic & $\boldsymbol{p}$-value \\
\hline Group PP-Statistic & -9.527 & 0.000 \\
\hline Group ADF-Statistic & -4.451 & 0.000 \\
\hline
\end{tabular}

\begin{tabular}{|l|c|c|}
\cline { 2 - 3 } \multicolumn{1}{c|}{} & \multicolumn{2}{c|}{ Kao Residual Test } \\
\cline { 2 - 3 } \multicolumn{1}{c|}{} & t-Statistic & Probability \\
\hline ADF & -5.530 & 0.000 \\
\hline
\end{tabular}

\begin{tabular}{|c|c|c|c|c|}
\hline \multicolumn{5}{|c|}{ Johansen Fisher Panel Cointegration Test } \\
\hline Hypothesized number of CEs & $\begin{array}{c}\text { Fisher } \\
\text { Statistic } \\
\text { (trace) }\end{array}$ & Probability & $\begin{array}{c}\text { Fisher } \\
\text { Statistic } \\
\text { (max } \\
\text { eigen } \\
\text { test) }\end{array}$ & Probability \\
\hline None & 219.30 & 0.000 & 162.40 & 0.000 \\
\hline At most 1 & 110.30 & 0.000 & 90.42 & 0.000 \\
\hline At most 2 & 82.31 & 0.000 & 82.31 & 0.000 \\
\hline
\end{tabular}


Dependent Variable: Cost of Importing

Independent Variables: Foreign Bank Claims, GDP Per Capita

\begin{tabular}{|c|c|c|c|c|}
\hline \multicolumn{5}{|c|}{ Pedroni Residual Cointegration Test } \\
\hline \multicolumn{5}{|c|}{ Common AR coefficients (within-dimension) } \\
\hline & & & Wei & \\
\hline & Statistic & $p$-value & Statistic & $p$-value \\
\hline Panel PP-Statistic & -6.636 & 0.000 & -5.746 & 0.00 \\
\hline Panel ADF-Statistic & -5.260 & 0.000 & -3.967 & 0.00 \\
\hline
\end{tabular}

\begin{tabular}{|l|c|c|}
\hline \multicolumn{3}{|l|}{ Individual AR coefficients (between-dimension) } \\
\hline & Statistic & $\boldsymbol{p}$-value \\
\hline Group PP-Statistic & -8.754 & 0.000 \\
\hline Group ADF-Statistic & -4.757 & 0.000 \\
\hline
\end{tabular}

\begin{tabular}{|l|c|c|}
\cline { 2 - 3 } \multicolumn{1}{c|}{} & \multicolumn{2}{c|}{ Kao Residual Test } \\
\cline { 2 - 3 } \multicolumn{1}{c|}{} & t-Statistic & Probability \\
\hline ADF & -5.341 & 0.000 \\
\hline
\end{tabular}

\begin{tabular}{|c|c|c|c|c|}
\hline \multicolumn{5}{|c|}{ Johansen Fisher Panel Cointegration Test } \\
\hline Hypothesized number of CEs & $\begin{array}{c}\text { Fisher } \\
\text { Statistic } \\
\text { (trace) }\end{array}$ & Probability & $\begin{array}{c}\text { Fisher } \\
\text { Statistic } \\
\text { (max } \\
\text { eigen } \\
\text { test) }\end{array}$ & Probability \\
\hline None & 196.60 & 0.000 & 131.60 & 0.000 \\
\hline At most 1 & 109.40 & 0.000 & 81.04 & 0.000 \\
\hline At most 2 & 101.10 & 0.000 & 101.10 & 0.000 \\
\hline
\end{tabular}


Dependent Variable: Time to Export

Independent Variables: Foreign Bank Claims, GDP Per Capita

\begin{tabular}{|c|c|c|c|c|}
\hline \multicolumn{5}{|c|}{ Pedroni Residual Cointegration Test } \\
\hline \multicolumn{5}{|c|}{ Common AR coefficients (within-dimension) } \\
\hline & & & Wei & \\
\hline & Statistic & $p$-value & Statistic & $p$-value \\
\hline Panel PP-Statistic & -5.378 & 0.000 & -6.415 & 0.00 \\
\hline Panel ADF-Statistic & -3.774 & 0.000 & -4.335 & 0.00 \\
\hline
\end{tabular}

\begin{tabular}{|l|c|c|}
\hline \multicolumn{3}{|l|}{ Individual AR coefficients (between-dimension) } \\
\hline & Statistic & $\boldsymbol{p}$-value \\
\hline Group PP-Statistic & -8.506 & 0.000 \\
\hline Group ADF-Statistic & -5.682 & 0.000 \\
\hline
\end{tabular}

\begin{tabular}{|l|c|c|}
\cline { 2 - 3 } \multicolumn{1}{c|}{} & \multicolumn{2}{c|}{ Kao Residual Test } \\
\cline { 2 - 3 } \multicolumn{1}{c|}{} & t-Statistic & Probability \\
\hline ADF & -4.481 & 0.000 \\
\hline
\end{tabular}

\begin{tabular}{|c|c|c|c|c|}
\hline \multicolumn{5}{|c|}{ Johansen Fisher Panel Cointegration Test } \\
\hline Hypothesized number of CEs & $\begin{array}{c}\text { Fisher } \\
\text { Statistic } \\
\text { (trace) }\end{array}$ & Probability & $\begin{array}{c}\text { Fisher } \\
\text { Statistic } \\
\text { (max } \\
\text { eigen } \\
\text { test) }\end{array}$ & Probability \\
\hline None & 200.20 & 0.000 & 149.90 & 0.000 \\
\hline At most 1 & 103.60 & 0.000 & 82.46 & 0.000 \\
\hline At most 2 & 86.24 & 0.000 & 86.24 & 0.000 \\
\hline
\end{tabular}


Dependent Variable: Cost of Export

Independent Variables: Foreign Bank Claims, GDP Per Capita

\begin{tabular}{|c|c|c|c|c|}
\hline \multicolumn{5}{|c|}{ Pedroni Residual Cointegration Test } \\
\hline \multicolumn{5}{|c|}{ Common AR coefficients (within-dimension) } \\
\hline & & & Wei & \\
\hline & Statistic & $p$-value & Statistic & $p$-value \\
\hline Panel PP-Statistic & -10.739 & 0.000 & -10.082 & 0.00 \\
\hline Panel ADF-Statistic & -8.439 & 0.000 & -7.113 & 0.00 \\
\hline
\end{tabular}

\begin{tabular}{|l|c|c|}
\hline \multicolumn{3}{|l|}{ Individual AR coefficients (between-dimension) } \\
\hline & Statistic & $\boldsymbol{p}$-value \\
\hline Group PP-Statistic & -10.968 & 0.000 \\
\hline Group ADF-Statistic & -7.436 & 0.000 \\
\hline
\end{tabular}

\begin{tabular}{|l|c|c|}
\cline { 2 - 3 } \multicolumn{1}{c|}{} & \multicolumn{2}{c|}{ Kao Residual Test } \\
\cline { 2 - 3 } \multicolumn{1}{c|}{} & t-Statistic & Probability \\
\hline ADF & -5.182 & 0.000 \\
\hline
\end{tabular}

\begin{tabular}{|c|c|c|c|c|}
\hline \multicolumn{5}{|c|}{ Johansen Fisher Panel Cointegration Test } \\
\hline Hypothesized number of CEs & $\begin{array}{c}\text { Fisher } \\
\text { Statistic } \\
\text { (trace) }\end{array}$ & Probability & $\begin{array}{c}\text { Fisher } \\
\text { Statistic } \\
\text { (max } \\
\text { eigen } \\
\text { test) }\end{array}$ & Probability \\
\hline None & 210.00 & 0.000 & 140.30 & 0.000 \\
\hline At most 1 & 114.00 & 0.000 & 83.58 & 0.000 \\
\hline At most 2 & 106.60 & 0.000 & 106.60 & 0.000 \\
\hline
\end{tabular}

